\title{
RNA Fingerprinting of Respiratory Syncytial Virus Using Ribonuclease Protection Application to Molecular Epidemiology
}

Gregory A. Storch,* Chung S. Park, ${ }^{*}$ and Dennis E. Dohner"

${ }^{*}$ Edward Mallinckrodt Department of Pediatrics, Washington University School of Medicine, St. Louis, Missouri 63110;

*Infectious Diseases Division, St. Louis Children's Hospital, St. Louis, Missouri, 63110; and ${ }^{\S}$ Research Service,

John Cochran Veterans Administration Hospital, St. Louis, Missouri 63125

\begin{abstract}
We have used the technique of ribonuclease protection to define genomic variation among circulating isolates of subgroup A respiratory syncytial (RS) virus. RNAs extracted from HEp-2 cells infected with strains to be analyzed were hybridized with a ${ }^{32} \mathbf{P}$-labeled RNA probe corresponding to the RS virus G glycoprotein (A2 strain). Areas of nonhomology were detected by cleavage with ribonuclease $A$. Using this technique, multiple distinct RNA cleavage patterns could be distinguished among viral isolates recovered from infants residing in the same metropolitan area and infected during the same epidemic season. Epidemiologically related isolates (from coinfected twins, from infants infected during a nosocomial outbreak at an extended care facility, and from institutionalized adults infected during an outbreak) yielded identical patterns. In two separate outbreaks, differences in cleavage patterns among certain isolates corresponded to epidemiologically significant differences among the individuals from whom the isolates were recovered. We conclude that substantial genomic heterogeneity exists among circulating isolates of subgroup A RS virus. Ribonuclease protection can be used as a molecular fingerprinting tool for expanded studies of the molecular epidemiology of this virus.
\end{abstract}

\section{Introduction}

Respiratory syncytial (RS) ${ }^{1}$ virus is the major cause of serious lower respiratory tract infection in infants $<1$ yr of age $(1,2)$. Early studies of RS virus that used polyclonal animal antisera to characterize numerous isolates found that most were indistinguishable, although occasional variants were detected (3-7). In the years after the discovery of the virus, numerous studies were carried out which elucidated the epidemiology of RS virus $(2,6,8-12)$. Because these studies were based on viral isolation and serology, methods that were not sensitive to variation among isolates, the studies were not able to discern epidemiologic differences related to subtypes or variant strains of the virus.

\footnotetext{
Address reprint requests to Dr. Gregory A. Storch, St. Louis Children's Hospital, 400 South Kingshighway, St. Louis, MO 63110.

Received for publication 21 November 1988 and in revised form 13 February 1989.
}

1. Abbreviations used in this paper: RS, respiratory syncytial virus.

J. Clin. Invest.

(c) The American Society for Clinical Investigation, Inc. 0021-9738/89/06/1894/09 \$2.00

Volume 83, June 1989, 1894-1902
With the development of monoclonal antibodies to RS virus, several laboratories recognized the existence of two subgroups of RS virus (13-17). The two subgroups, designated A and $B(14)$ or 1 and $2(13,17)$ have been shown to occur in numerous geographic areas (13-21). Both subgroups are found in the community at the same time, but the relative proportions vary according to year and location $(13-15,17-19,21)$. More detailed studies of the epidemiology, immunology, and clinical aspects of the two subgroups are still at an early stage (22-26).

Although the recognition of the two subgroups of RS virus is an important step, there remains a need for a higher resolution fingerprinting technique capable of differentiating among individual strains or isolates within either of the two subgroups of RS virus. Such a system would take advantage of naturally occurring variation among isolates, and would be applicable to studies of molecular epidemiology and pathogenesis. Evidence of both structural and antigenic variation among isolates has been reported in both subgroups (16, 17, 19, 20, 25, 27-33), suggesting that sufficient variation may exist to make fingerprinting possible. The recent finding of $4 \%$ nonhomology in the nucleotide sequences of $\mathrm{mRNAs}$ encoding for the $\mathrm{G}$ glycoprotein of the A2 and Long strains of subgroup A RS virus (34) also supports the possibility of unique identification of strains.

In this study, we have used the technique of ribonuclease protection analysis (35) to examine the extent of genomic diversity among isolates of subgroup $A \mathrm{RS}$ virus. This technique has been shown by others to be very sensitive for detecting small changes in RNA sequences including single-base substitutions (35). The main application previously has been to studies of human genetics (35-39). One study has used the technique to analyze genomic variation in influenza $A$ virus (40). In addition to using the technique to reveal genomic diversity among circulating isolates of subgroup A RS virus, we also demonstrate its use as a molecular fingerprinting tool in the epidemiologic analysis of two outbreaks of RS virus.

\section{Methods}

Virus strains and cells. The Long strain of RS virus (41) was obtained from the American Type Culture Collection (Rockville, MD; ATCCVR-26), and the A2 strain (42) was kindly supplied by Dr. Robert Chanock, National Institutes of Health, Bethesda, MD. Patient isolates were suppled by the Virology Laboratory of the Washington University Department of Pediatrics at St. Louis Children's Hospital (SLCH). These isolates were grown in HEp-2 or human diploid fibroblast (MRC-5) cells from nasopharyngeal swabs or aspirates obtained from infants hospitalized at SLCH because of acute respiratory infection. Isolates from an outbreak of RS virus infection among institutionalized adults (25) were kindly supplied (under code) by Dr. Lawrence Corey, University of Washington, Seattle, WA, and Dr. Larry J. Anderson, Centers for Disease Control, Atlanta, GA. Isolates from an 
outbreak at an extended care facility for children in St. Louis were initially recovered from patient specimens in the Virology Laboratory at SLCH or the Virology Laboratory at Cardinal Glennon Children's Hospital. The isolates from the Cardinal Glennon Hospital Laboratory were kindly supplied by Dr. Ella Swierkosz, Departments of Pediatrics and Pathology, St. Louis University, St. Louis, MO.

Except where otherwise specified, RS virus was propagated in HEp-2 cells originally obtained from Flow Laboratories (McLean, VA). Growth media consisted of Eagle's MEM supplemented with 2 $\mathrm{mM}$ glutamine, nonessential amino acids, $100 \mathrm{U} / \mathrm{ml}$ penicillin, 100 $\mu \mathrm{g} / \mathrm{ml}$ streptomycin, and $1 \mu \mathrm{g} / \mathrm{ml}$ amphotericin B. Plaque media consisted of viral growth media containing $1 \%$ methyl cellulose.

$M A b$ analysis. All isolates were subjected to antigenic analysis using a panel of six MAb that recognize the $G$ glycoprotein of $R S$ virus, including five that can distinguish between subgroup $A$ and subgroup B RS virus (17). These MAb can also distinguish selected prototype strains from one another. The MAb used and the prototype strains recognized were CA2 (Long and A2), B4 (Long), CD7 (A2), DB3 (CH 18537 and 9320), $\mathrm{AB} 10$ (CH 18537), and BD5 (cross-reacting). The pattern of reactivity of each isolate with the MAb was defined using fluorescent antibody staining as previously described (17).

Purification of whole cell RNA. Cell RNAs were harvested from RS virus-infected or uninfected cultures of HEp- 2 cells grown in $75-\mathrm{cm}^{2}$ tissue culture flasks. Harvests from infected cells were carried out when early cytopathic effect was visible before extensive cell destruction had occurred. Purification of cell RNAs was by the guanidinium isothiocyanate-cesium chloride centrifugation method described by Chirgwin et al. (43) and Maniatis et al. (44). Infected or uninfected control HEp-2 cell monolayers were rinsed with PBS and then lysed with $3 \mathrm{ml}$ of a solution containing $6 \mathrm{M}$ guanidinium isothiocyanate, $50 \mathrm{mM}$ Tris- $\mathrm{HCl} \mathrm{pH}$ 7.5, $10 \mathrm{mM}$ EDTA pH 7.5, 0.5\% sodium sarkosyl, and $0.2 \mathrm{M}$ 2-mercaptoethanol. One gram of $\mathrm{CsCl}$ was added to each $2.5 \mathrm{ml}$ of lysate; the lysate was then layered over $1.2 \mathrm{ml}$ of $5.7 \mathrm{M} \mathrm{CsCl}$ in $0.1 \mathrm{M}$ EDTA pH 7.5 and centrifuged at $35,000 \mathrm{rpm}$ for $16 \mathrm{~h}$ at $20^{\circ} \mathrm{C}$ in a rotor (model SW50.1; Beckman Instruments, Fullerton, CA). The RNA pellet was dissolved in $10 \mathrm{mM}$ Tris- $\mathrm{HCl}$ pH 7.5, 5 mM EDTA (pH 7.5), 1\% SDS, and extracted twice with chloroform/1-butanol (4:1). The RNA was precipitated by the addition of $0.1 \mathrm{vol}$ of $3 \mathrm{M}$ sodium acetate pH 5.5 and 2.5 vol of ethanol. The RNA was pelleted, redissolved in water, and precipitated again with ethanol.

Synthesis of RNA probes. The RS virus G glycoprotein cDNA clone (A2 strain) in the plasmid vector pAG-2 was obtained from Dr. Gail Wertz (University of Alabama, Birmingham, AL) $(45,46)$ and subcloned into the Bam HI site of the transcription plasmid pGEM-3 (Promega Biotec, Madison, WI). ${ }^{32} \mathrm{P}$-labeled RNA transcripts were synthesized using SP6 and T7 RNA polymerase transcription reagents obtained from Promega Biotec and used according to the supplier's directions. Alpha- ${ }^{32}$ P-CTP was obtained from Dupont-New England Nuclear (Boston, MA). Template for the transcription reactions was 1 $\mu \mathrm{g}$ of the recombinant plasmid resulting from insertion of the RSV G glycoprotein cDNA into pGEM-3. The plasmid was linearized using Xba I for T7 polymerase transcription and Sma I for SP6 polymerase transcription. Restriction enzymes were obtained from New England Biolabs (Beverly, MA), Bethesda Research Laboratories (Gaithersburg, MD), or International Biotechnologies, Inc. (New Haven, CT) and used according to the supplier's instructions. Analysis of the size of fragments resulting from digestion of the recombinant plasmid with the restriction enzymes Pst I and Hinc II suggested that the orientation of insertion of the RSVG cDNA within the recombinant plasmid was such that the transcript prepared using the T7 polymerase was complementary to viral mRNA and the transcript prepared using the SP6 polymerase was complementary to the virion RNA (data not shown).

After transcription, the ${ }^{32} \mathrm{P}$-labeled RNA transcripts were extracted with phenol/chloroform/isoamyl alcohol (25:24:1) and chloroform/ isoamyl alcohol (24:1), precipitated with sodium acetate-ethanol, dried under vacuum, and dissolved in $30 \mu \mathrm{l}$ of $80 \%$ formamide buffer ( 40 $\mathrm{mM}$ piperazine- $N, N^{\prime}$-bis(2-ethane sulfonic acid) [pH 6.65], $400 \mathrm{mM}$ $\mathrm{NaCl}$, and $1 \mathrm{mM}$ EDTA [pH 8] in $80 \%$ formamide).
Hybridization and ribonuclease protection procedure. The application of ribonuclease protection analysis to examine the extent of variation among different isolates of RS virus is shown in Fig. 1. The procedure used was based on that described by Myers et al. (35). $1 \mu$ l of ${ }^{32} \mathrm{P}$-labeled transcript was mixed with $2 \mu \mathrm{g}$ of unlabeled RNA in $29 \mu \mathrm{l}$ of $80 \%$ formamide buffer. The RNAs were denatured by incubation for $10 \mathrm{~min}$ at $85^{\circ} \mathrm{C}$ and then incubated $\sim 16 \mathrm{~h}$ at $45^{\circ} \mathrm{C}$ to allow hybridization to occur. The samples were cooled to room temperature, $350 \mu \mathrm{l}$ of cold RNase digestion solution was added (RNase digestion solution contained $10 \mathrm{mM}$ Tris- $\mathrm{HCl}$ pH 7.5, 1 mM EDTA pH 8, 200 $\mathrm{mM} \mathrm{NaCl}, 100 \mathrm{mM} \mathrm{LiCl}$, and $10 \mu \mathrm{g} / \mathrm{ml}$ RNase A). Ribonuclease digestion was for $30 \mathrm{~min}$ at $20^{\circ} \mathrm{C}$. $24 \mu \mathrm{l}$ of a solution containing $10 \%$ SDS, $2.5 \mathrm{mg}$ proteinase $\mathrm{K} / \mathrm{ml}$, and $104 \mu \mathrm{g}$ yeast $\mathrm{RNA} / \mathrm{ml}$ was then added and digestion continued for an additional $30 \mathrm{~min}$ at $37^{\circ} \mathrm{C}$ to remove the ribonuclease. The RNA was finally purified by two phenol/chloroform/isoamyl alcohol (25:24:1) extractions and ethanol precipitation. The protected fragments were visualized after heat denaturation by either 4 or $8 \%$ polyacrylamide/ $8 \mathrm{M}$ urea gel electrophoresis or glyoxal denaturation followed by $4 \%$ NuSieve (FMC BioProducts Corp., Rockland, ME) agarose gel electrophoresis (47).

Gel electrophoresis: glyoxal/agarose and polyacrylamide/urea. All electrophoresis was performed basically as described by Maniatis et al.
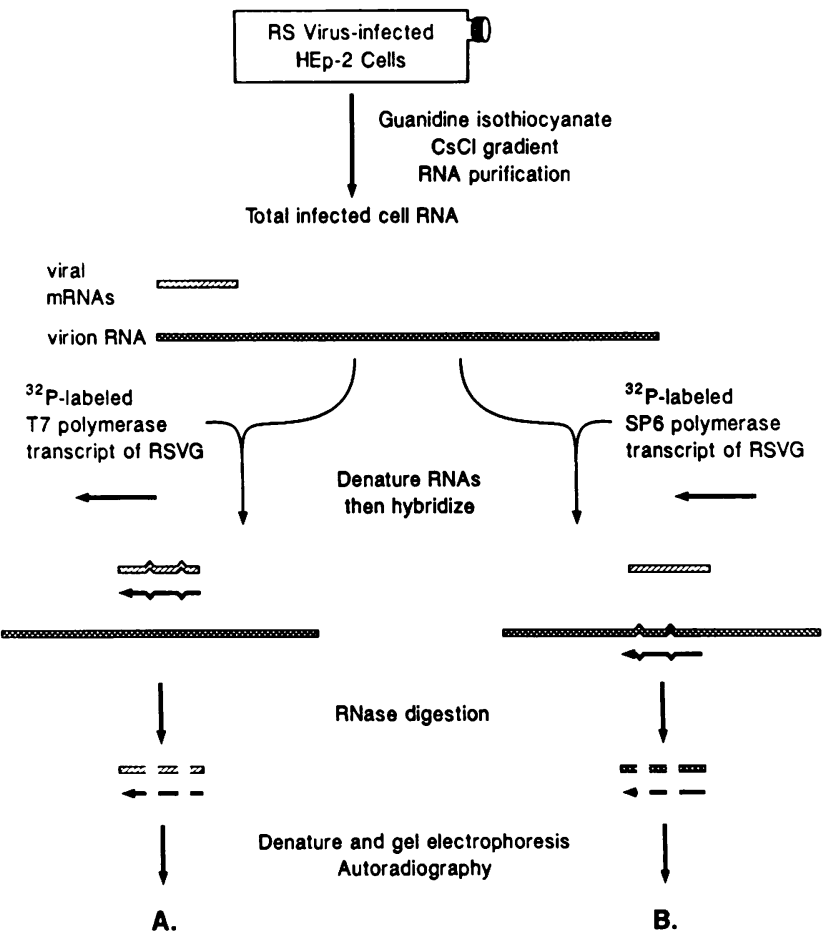

Figure 1. Ribonuclease protection analysis of RS virus. RNA was extracted using the guanidinium isothiocyanate-cesium chloride method (details in text) from HEp-2 cells infected with the isolate of RS virus to be analyzed, and incubated with ${ }^{32} \mathrm{P}$-labeled RNA probes transcribed from RS virus G glycoprotein CDNA as described in the text. The reaction was performed separately using the RNA probes complementary to viral mRNA (left) and virion RNA (right). After hybridization, the reaction mixture was cooled and ribonuclease $A$ was added. Cleavage was stopped after $30 \mathrm{~min}$ by adding SDS and proteinase $\mathrm{K}$. After incubation with proteinase $\mathrm{K}$, the cleavage products were purified by phenol/chloroform extraction and ethanol precipitation. Regions of nonhomology are subject to digestion by ribonuclease A. Two such regions are shown. The protected fragments were visualized by either 4 or $8 \%$ polyacrylamide $/ 8 \mathrm{M}$ urea gel electrophoresis or glyoxal denaturation and $4 \%$ agarose gel electrophoresis as described in the text, followed by autoradiography. 
(47). $4 \%$ polyacrylamide/8 $\mathrm{M}$ urea gel electrophoresis was performed in a dual vertical slab gel electrophoresis cell (Protean; BioRad Laboratories, Richmond, CA) for $2 \mathrm{~h}$ at $350 \mathrm{~V}$. For some runs, 4 or $8 \%$ polyacrylamide/ $8 \mathrm{M}$ urea gel electrophoresis was performed in a sequencing gel apparatus (model SE 1500; Hoefer Scientific Instruments, San Francisco, CA) using a prerun of $1 \mathrm{~h}$ at $110 \mathrm{~W}$ and then electrophoresis for $1 \mathrm{~h}$ at $120 \mathrm{~W}$ or $1.5 \mathrm{~h}$ at $115 \mathrm{~W}$. Glyoxal/4\% agarose (NuSieve; FMC Bioproducts) gels were run for $6 \mathrm{~h}$ at $150 \mathrm{~V}$ in a gel chamber (model HRH, International Biotechnologies) with buffer circulation and cooling. 4\% NuSieve agarose (FMC BioProducts Corp.) was used for separation of RNase-protected fragments. ${ }^{32} \mathrm{P}$-labeled bands were visualized by autoradiography using Kodak XAR-5 film exposed at room temperature. An intensifying screen was used when necessary to enhance exposure.

\section{Results}

Diversity among isolates. Two prototype type A strains (Long and A2) and five clinical isolates (5383, 10263, 10346, 10348, and 10667) recovered from infants hospitalized at SLCH were analyzed. The A2 strain is the same strain from which the RS virus $\mathrm{G}$ glycoprotein RNA was cloned. However, note that the strain of $A 2$ used in these analyses had been in our laboratory for $\sim 4 \mathrm{yr}$, whereas the cloning of the A2 G glycoprotein RNA was carried out by the laboratory of Dr. Gail Wertz using a culture of A2 maintained in that laboratory. The panel of $\mathrm{MAb}$ to the $\mathrm{G}$ glycoprotein was able to distinguish the Long and $A 2$ strains from one another and from the clinical isolates, but did not distinguish among the clinical isolates (17).

The patterns obtained using transcripts prepared with the T7 and SP6 polymerases are shown in Fig. 2 ( $A$ and $B$, respectively). The Long and A2 strains can be clearly differentiated from each other using either transcript. The lack of clearly defined bands seen after ribonuclease cleavage of hybrids formed from labeled transcript and the A2 strain from our laboratory is consistent with the identity of this strain and the A2 strain used to produce the G glycoprotein cDNA from which the RNA was transcribed. A similar pattern was observed when unlabeled transcript prepared from the $G$ glycoprotein CDNA was hybridized with the labeled probes (not shown). The five clinical isolates yielded three distinct patterns, each different from those of the Long and A2 strains. Although the patterns resulting from use of transcripts prepared with the T7 and SP6 systems are different, the same grouping of isolates resulted from the use of either transcript.

Analysis of genomic diversity within a single culture. To examine whether genomic variation existed within a single

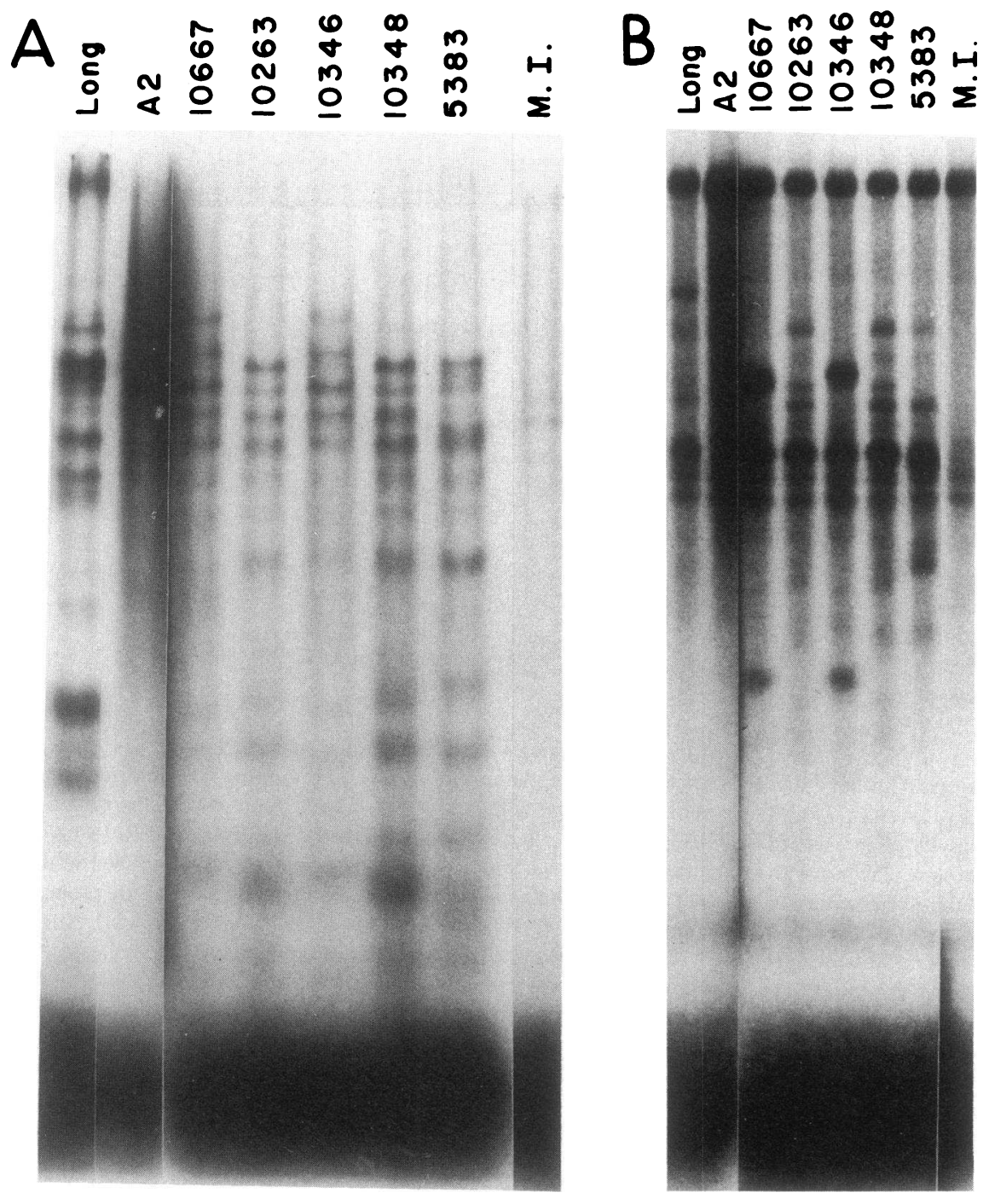

Figure 2. Ribonuclease protection analysis of two prototype strains (Long and A2) and five clinical isolates $(10667,10263$, 10346, 10348, and 5383) of RS virus. $(A)$ Results obtained using the ${ }^{32} \mathrm{P}$-labeled RNA probe prepared from plasmid DNA linearized with $\mathrm{Xba} I$ and $\mathrm{T} 7$ polymerase (thought to be complementary to viral mRNA). (B) shows results obtained using the ${ }^{32} \mathrm{P}$-labeled RNA probe prepared from plasmid DNA linearized with Sma I and SP6 polymerase (thought to be complementary to virion RNA). Mock-infected cells are designated M.I. The cleavage products were separated by glyoxal/agarose gel electrophoresis. 
culture, six individual plaques from a culture of the Long strain grown under growth media containing $1 \%$ methyl cellulose were selected and subjected to an additional plaque purification. RNA was extracted from HEp- 2 cells infected with each of the six plaque-purified clones and analyzed as described. No differences among the clones were apparent using the transcripts prepared with either the T7 or the SP6 polymerases (not shown).

Effect of multiple laboratory passages. To examine whether genomic changes would occur with multiple laboratory passages, a clinical isolate (5383) was passaged 10 times in HEp-2 cells. RNA was extracted and analyzed from passage levels 4, 7 , and 10 . No differences in cleavage patterns were apparent using either transcript (not shown).

Analysis of serial isolates from individual patients. Serial isolates from four infants were available for analysis. Two of the four were twins who had the onset of symptoms within 24 $h$ of one another and thus presumably were infected from the same source. The others were epidemiologically unrelated. Isolates recovered from specimens taken two days apart from each of the twins (SL5 and SL6) yielded identical patterns (Fig. 3). Two isolates recovered from specimens taken one day apart from a third patient (SL1) yielded patterns that were identical to each other and to those of SL5 and SL6. Two isolates recovered from specimens taken $6 \mathrm{~d}$ apart from the fourth patient (SL2) yielded patterns identical to one another and different from the patterns resulting from analysis of isolates from the other three patients. In all instances, relationships among isolates defined using the $\mathrm{T} 7$ polymerase transcript were the same upon analysis using the SP6 polymerase transcript.

Analysis of isolates from outbreaks. Seven isolates from an outbreak of RS virus in institutionalized adults (25) were available for study. The outbreak involved four young adult residents and one staff member of hall $A$ and two young adult residents of hall $B$ at the institution. Antigenic analysis of the isolates by Finger et al. (25) using MAb revealed that all of the isolates were subgroup $A$, and that they could be separated into two distinct groups based on the reactivity with the MAb. The groups corresponded to the two halls with which the patients were associated. Ribonuclease protection analysis of the isolates in our laboratory also revealed two separate cleavage patterns (Fig. 4). Isolates F4572, F4578, F4603, F4609, and S1979 had a similar pattern, which was distinct from that of $\mathrm{H} 1586$ and H1603. This grouping of isolates corresponds to the halls with which the individuals were associated and with the grouping derived from the MAb analysis. The same grouping of isolates occurred using the transcripts prepared with either the SP6 or T7 polymerase (not shown).

In January and February 1988, an outbreak of RS virus infection occurred among infants residing at an extended care facility in St. Louis. All seven infants in the nursery of the facility during the time period were affected. Three additional infants had manifestations of $\mathrm{RS}$ virus infection present at the time they were admitted to the facility. Two of these infants were housed in rooms other than the nursery until their manifestations resolved. RS virus isolates were available from five of the infants, including four who became infected in the nursery (SL7-10) and one who had clinical manifestations suggesting that he was already infected at the time of admission (SL11). Three of the isolates were from specimens submitted to the Virology Laboratory at SLCH and two were from specimens submitted to the Virology Laboratory at Cardinal Glen-

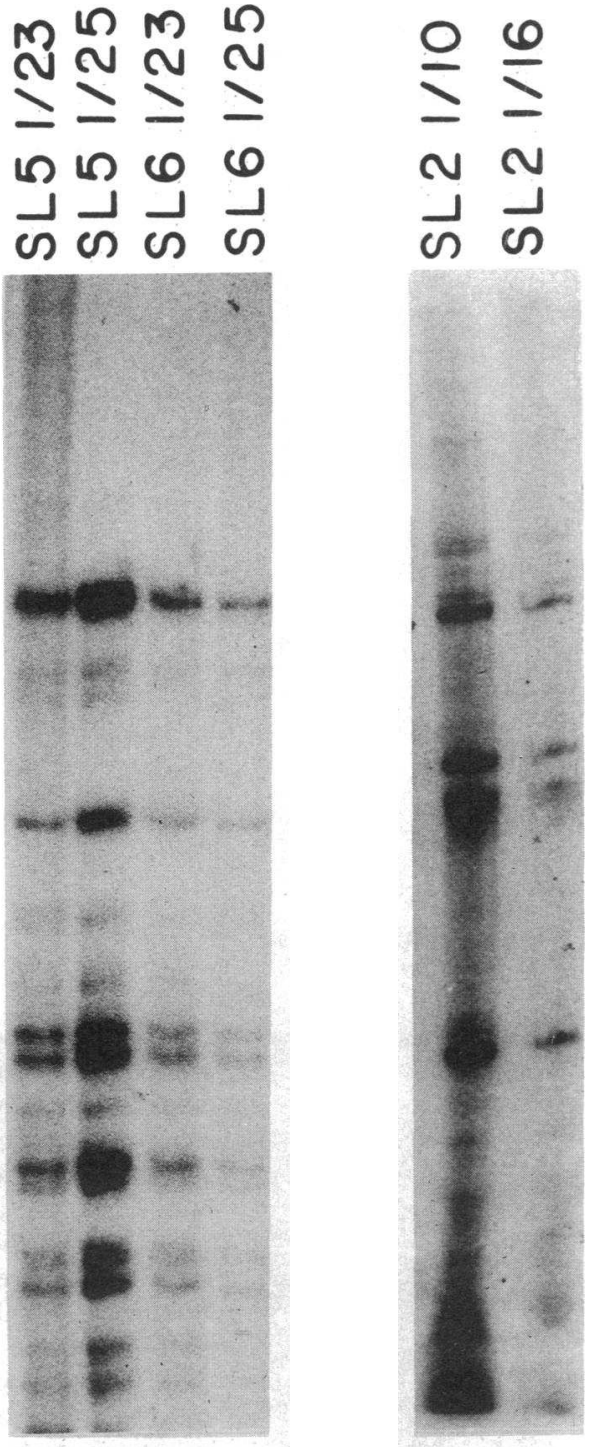

Figure 3. Ribonuclease protection analysis of serial isolates of RS virus recovered from infected infants. Nasopharyngeal swabs or aspirates were taken on two or more occasions during the hospitalization of four infants infected with RS virus. All analyses used the ${ }^{32}$ P-labeled RNA transcript prepared from plasmid DNA linearized with $\mathrm{Xba} I$ and transcribed using the $\mathrm{T} 7$ polymerase. Cleavage products of RNAs from SL1, SL5, and SL6 were separated by $8 \%$ polyacrylamide/8 M urea gel electrophoresis. Those from SL2 were separated by $4 \%$ polyacrylamide/ $8 \mathrm{M}$ urea gel electrophoresis.

non Children's Hospital. Fluorescent antibody staining using the panel of $\mathrm{MAb}$ to the $\mathrm{G}$ glycoprotein indicated that all five isolates were subgroup $A$. The reactivity of the five isolates with the panel of monoclonal antibodies was identical to one another, and corresponded to the pattern seen previously with analysis of type A isolates from infants in St. Louis (reactivity only with MAb CA2 and BD5) (17). Analysis of RNA from the five isolates revealed that the cleavage patterns of the four isolates from infants infected in the nursery were identical to one another using either transcript, whereas the cleavage pattern from SL11, the infant already symptomatic at the time of admission, was unique (Fig. 5).

Additional analysis of diversity. To facilitate comparison, hybridized and digested RNA from the Long strain and 10 


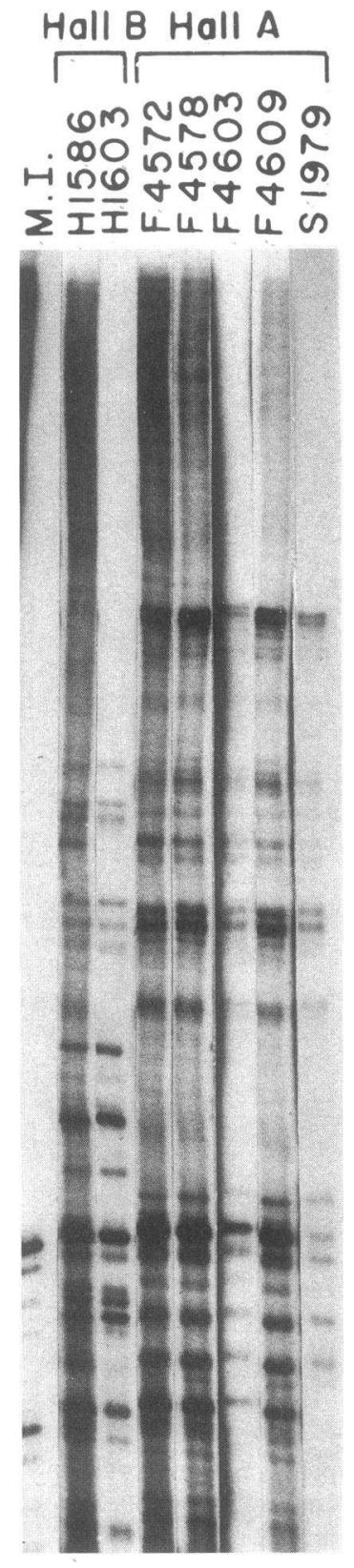

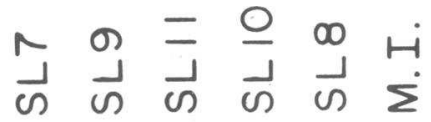

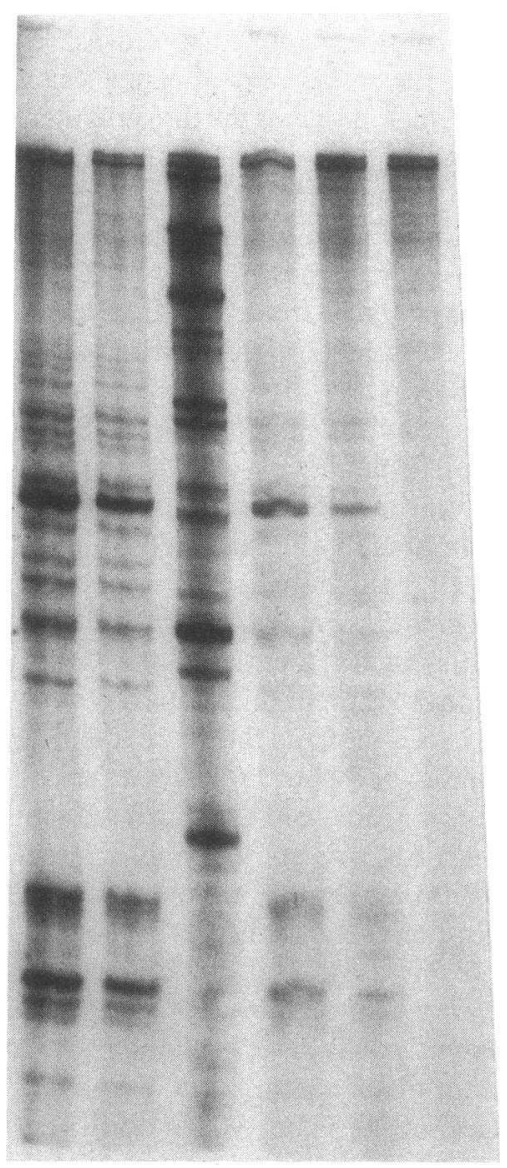

Figure 5. Ribonuclease protection analysis of $\mathrm{RS}$ virus isolates recovered from five infants residing in an extended care facility. The patients from whom SL7-10 were recovered acquired their illness while residing at the facility. The patient from whom SL11 was recovered was ill at the time of admission to the facility. RNA from each isolate was analyzed using the ${ }^{32} \mathrm{P}$-labeled transcript prepared from plasmid DNA linearized with Xba I and transcribed using the T7 polymerase. The cleavage products were separated by $4 \%$ polyacrylamide/8 $\mathrm{M}$ urea gel electrophoresis. analyzed using the ${ }^{32} \mathrm{P}$-labeled transcript prepared from DNA linearized with $\mathrm{Xba} I$ and transcribed using the $\mathrm{T} 7$ polymerase. The cleavage products were separated by $8 \%$ polyacrylamide $/ 8 \mathrm{M}$ urea gel electrophoresis. The lane with $\mathrm{S} 1979$ is a different exposure of the same autoradiogram. Mock-infected cells are designated M.I.

clinical isolates were run on the same gel (Fig. 6). The 10 clinical isolates included single isolates from the four patients whose isolates were examined in the study of variation in serial isolates, two additional isolates from patients with community-acquired RS virus infection hospitalized at St. Louis Children's Hospital during the winter of 1987-1988, and isolates representative of each of the two patterns were found in the Seattle and St. Louis outbreaks.

All isolates other than the prototype strain Long had the same pattern of reactivity with the panel of MAb to the RS virus $\mathrm{G}$ glycoprotein. The results of ribonuclease cleavage patterns from HEp-2 cells infected with each of the 10 isolates revealed six distinct patterns, designated $a-f$, each of which was different from that of the Long strain. The grouping of the isolates according to their ribonuclease cleavage patterns is shown in Table I. Isolate SL1 yielded a cleavage pattern identical to that of isolates SL5 and SL6, which were recovered

from coinfected identical twins. The patient from whom SL1 was recovered lived in a different region of the St. Louis metropolitan area from the twins, and there was no known connection between the families. Isolates SL3 and SL4 yielded patterns identical to one another and different from that of all other isolates. These two isolates were recovered from infants who lived in different communities, and had no known connection with each other. Isolate SL2, which yielded a unique pattern, was recovered from an infant who lived in a community 90 miles from St. Louis. SL7 was chosen as representative of the outbreak strain at the extended care facility in St. Louis. This pattern was also different from any other pattern seen. Interestingly, SL11, the isolate recovered in 1988 from the infant who was ill at the time of admission to the extended care facility, yielded a cleavage pattern that was identical to that of $\mathrm{H} 1586$, one of the isolates recovered in 1985 from a resident of Hall B of the Seattle institution. The pattern of F4603, chosen as representative of the isolates from hall $A$ at the Seattle institution, was unique.

\section{Discussion}

The work reported in this paper is an effort to develop a highresolution molecular fingerprinting technique capable of distinguishing among individual isolates of RS virus. Certain de- 


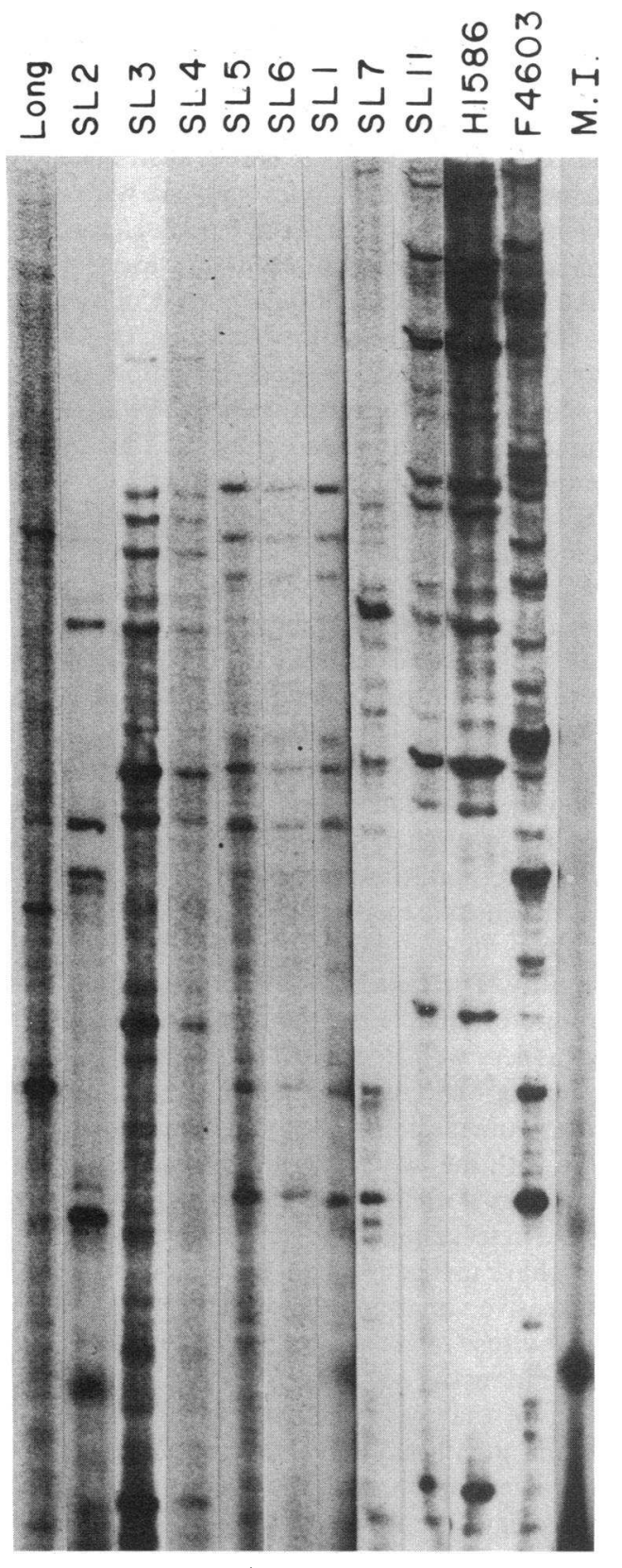

Figure 6. Ribonuclease protection analysis of RNA extracted from multiple isolates of RS virus from children infected in the St. Louis metropolitan area during the same RS virus season and from two isolates from individuals infected in Seattle in a different RS viris season. RNA from each isolate was analyzed using the ${ }^{32} \mathrm{P}$-labeled transcript prepared from plasmid DNA linearized with Xba I and transcribed using the $\mathrm{T} 7$ polymerase. The cleavage products were separated by $8 \%$ polyacrylamide/ $8 \mathrm{M}$ urea gel electrophoresis. Lanes shown are different exposures of the same gel. Additional information concerning these isolates is in Table $I$.

tailed epidemiologic and pathophysiologic studies of infectious agents require such capability. For example, a number of aspects of the epidemiology and pathophysiology of human herpes virus infections could only have been defined using the technique of restriction endonuclease analysis to distinguish among individual strains. The major reasons that genome fingerprinting techniques are more widely available for DNA vi-
Table I. Grouping of Isolates of RS Virus According to the Results of Ribonuclease Protection

\begin{tabular}{|c|c|c|c|c|}
\hline $\begin{array}{l}\text { Ribonuclease } \\
\text { cleavage } \\
\text { pattern }\end{array}$ & Isolate(s) & $\begin{array}{c}\text { Date of } \\
\text { onset }\end{array}$ & Residence & Comment \\
\hline$a$ & SL2 & $1 / 9 / 88$ & Mt. Vernon, IL & \\
\hline$b$ & $\begin{array}{l}\text { SL3 } \\
\text { SL4 }\end{array}$ & $\begin{array}{l}1 / 16 / 88 \\
1 / 17 / 88\end{array}$ & $\begin{array}{l}\text { St. Louis City, MO } \\
\text { Belleville, IL }\end{array}$ & \\
\hline$c$ & $\begin{array}{l}\text { SL5 } \\
\text { SL6 } \\
\text { SL1 }\end{array}$ & $\begin{array}{l}1 / 11 / 88 \\
1 / 21 / 88 \\
1 / 16 / 88\end{array}$ & $\begin{array}{l}\text { St. Louis City, MO } \\
\text { St. Louis City, MO } \\
\text { University City, MO }\end{array}$ & $\begin{array}{l}\text { Twin of SL6 } \\
\text { Twin of SL5 }\end{array}$ \\
\hline$d$ & $\begin{array}{l}\text { SL7 } \\
\text { SL8 } \\
\text { SL9 } \\
\text { SL10 }\end{array}$ & $\begin{array}{l}1 / 21 / 88^{*} \\
1 / 27 / 88^{*} \\
1 / 27 / 88^{*} \\
2 / 2 / 88^{*}\end{array}$ & $\begin{array}{l}\text { St. Louis City, MO } \\
\text { St. Louis City, MO } \\
\text { St. Louis City, MO } \\
\text { St. Louis City, MO }\end{array}$ & $\begin{array}{l}\text { Nosocomial } \\
\text { acquisition at an } \\
\text { extended care } \\
\text { facility }\end{array}$ \\
\hline$e$ & $\begin{array}{l}\text { H1586 } \\
\text { H1603 }\end{array}$ & $\begin{array}{l}4 / 85 \\
4 / 85\end{array}$ & $\begin{array}{l}\text { Seattle, WA } \\
\text { Seattle, WA }\end{array}$ & $\begin{array}{l}\text { Illness present when } \\
\text { admitted to } \\
\text { extended care } \\
\text { facility } \\
\text { Residents of hall B } \\
\text { at an institution } \\
\text { for the mentally } \\
\text { retarded }\end{array}$ \\
\hline$f$ & $\begin{array}{l}\text { F4572 } \\
\text { F4578 } \\
\text { F4603 } \\
\text { F4609 }\end{array}$ & $\begin{array}{l}3 / 85 \\
3 / 85 \\
3 / 85 \\
3 / 85\end{array}$ & $\begin{array}{l}\text { Seattle, WA } \\
\text { Seattle, WA } \\
\text { Seattle, WA } \\
\text { Seattle, WA }\end{array}$ & Residents of hall A \\
\hline$f$ variant & S1979 & $3 / 85$ & Seattle, WA & $\begin{array}{l}\text { Staff member of } \\
\text { hall } \mathbf{A}\end{array}$ \\
\hline
\end{tabular}

* Date of diagnosis.

ruses than RNA viruses, especially those such as RS virus that have a nonsegmented genome, are probably the greater technical ease of working with DNA, and the availability of a wide range of restriction endonucleases for cleaving DNA at sequence-specific sites. The technique that has been most widely used to characterize the genome of nonsegmented RNA viruses is ribonuclease $\mathrm{T} 1$ oligonucleotide fingerprinting (48-50). Although widely used, this technique is not ideal because it is relatively cumbersome, and allows analysis of $<15 \%$ of the viral genome of RNA viruses (49).

For many RNA viruses, including RS virus, the major approach to studying variation among isolates has been the use of $M A b$. Antigenic analysis using MAb has revealed the existence of two distinct subgroups of RS virus (13-17), and has permitted limited discrimination among strains within the subgroups $(13,15,17,33)$. We reasoned that considerable additional diversity might be revealed by analysis of the genome, because some detectable genome differences might not result in either structural or antigenic changes in the corresponding proteins. To search for these differences, we used the ribonuclease protection technique, as described by Myers et al. (35). The method takes advantage of the resistance of double-stranded RNA to cleavage by ribonuclease $A$. To use the technique, a ${ }^{32} \mathrm{P}$-labeled RNA probe chosen to correspond to a nucleotide sequence of interest is incubated under appropriate conditions with the RNA being analyzed. Hybridization of the target RNA with the probe protects homologous regions of the probe from ribonuclease cleavage, while areas of mismatch are susceptible to cleavage. Because the action of ribonuclease $A$ is to cleave at the 3'-phosphate of pyrimidine nucleotides, not all mismatches are detected (35). 
In applying ribonuclease protection to RS virus, we used an RNA probe corresponding to the $\mathrm{G}$ glycoprotein of the $\mathrm{A} 2$ strain, a prototype subgroup A strain. This RNA was chosen because the $G$ glycoprotein displays the most strain-to-strain variation among the individual $\mathrm{RS}$ virus proteins $(14,22,26$, 31). The target RNA was whole cell RNA extracted from HEp-2 cells infected with the strain or isolate to be analyzed. The ability to use RNA from infected cells without having to purify the target virus is an important practical advantage of the method, which has also been demonstrated by Lopez-Galindez et al. in studies of the influenza hemagglutinin gene (40). Not surprisingly in light of the extensive sequence differences known to exist in the genes encoding for the G glycoprotein of subgroup A and B strains (34), the probe derived from the A2 strain did not hybridize with RNA from cells infected with subgroup B strains. Thus, at this time our analysis is limited to subgroup A strains, although it is likely that with the availability of cloned DNA from a subgroup B strain, ribonuclease protection can be used to analyze subgroup B strains as well.

In addition to its sensitivity for detecting single base-pair mismatches; ribonuclease protection analysis has other methodological advantages. One is that it is relatively simple to carry out. Only the RNA probe is radiolabeled, obviating the need to radiolabel each isolate being analyzed. A second is that unlike techniques such às ribonuclease $\mathrm{T} 1$ oligonucleotide fingerprinting that require more cumbersome two-dimensional gel electrophoresis, ribonuclease protection analysis allows multiple isolates to be analyzed on the same gel, facilitating direct comparison. We have not yet fully evaluated the capability for comparing isolates analyzed in different experiments. That some of the RNA cleavages are partial and are influenced by experimental conditions (35) suggests the need for caution in making such comparisons. Future efforts at careful standardization of experimental conditions may make interexperiment comparisons possible.

Our application of ribonuclease protection analysis to a group of subgroup A isolates was successful in detecting individual fingerprints among a collection of subgroup $A$ isolates that had been recovered from infants infected in the same metropolitan area during the same RS virus epidemic season. As expected, epidemiologically related strains had identical fingerprints. Although extensive variation was demonstrable, it is also noteworthy that some epidemiologically unrelated isolates also yielded indistinguishable patterns. It is particularly interesting that one isolate from St. Louis in 1988 was apparently identical to an isolate from Seattle in 1985. This finding suggests the possible existence of discrete variants within subgroup $A$ RS virus. If such stable variants exist, they might be of epidemiologic, pathogenetic, or clinical importance, particularly in relation to the phenomena of multiple RS virus infections in individual patients and the occurrence of yearly epidemics of RS virus infection. Further studies are now possible to investigate these questions.

In applying a technique that is expected to be very sensitive to small differences in the genome, it was important to define the extent of background variability, to determine the extent of difference required to conclude that two isolates were unrelated. This question is particularly relevant to studies of an RNA virus because of the error proneness of viral RNA polymerases (51). However, no differences were detected among individual clones isolated and purified from within a single culture, in multiple laboratory passages within the same laboratory, or in serial isolates from the same patient during a single episode of RS virus infection. That genomic diversity was not detected in the $\mathrm{G}$ glycoprotein gene in these experiments should not be taken as evidence that no such diversity exists. In the analysis of individual clones, only six were analyzed, and thus small subpopulations could have been missed. In addition, ribonuclease protection would not be expected to be sensitive to the presence of small populations of variant RNA species possibly present even within one clone. However, the importance of the findings is that the in-laboratory reproducibility of the method is not adversely affected by diversity that might be present within a single culture or that might result from a limited number of laboratory passages.

The potential power of a technique that can distinguish among epidemiologically unrelated strains of RS virus is illustrated by the two outbreaks that were analyzed. The Seattle outbreak strains had previously been analyzed by Finger et al. using MAb. That analysis revealed that the viruses isolated from individuals with RS infection could be separated into two groups, corresponding to two halls with which the ill individuals were associated (25). The isolates from this outbreak were used as an opportunity to validate the ribonuclease protection technique. Indeed, the groupings of isolates resulting from the protection analysis corresponded to those of the MAb analysis. In the outbreak at the chronic care facility, fingerprinting confirmed that the illness in one patient was unrelated to the outbreak at the facility. The capacity to make similar distinctions will be even more valuable in other outbreaks in which the epidemiology is less well defined. The relative roles of antigenic analysis using MAb and analysis of the genome by techniques such as ribonuclease protection will become more clear as experience with the two types of analysis is accumulated. Our anticipation is that genome analysis will reveal some differences not detectable by antigenic analysis.

In summary we have used a new viral genome-based technique to reveal extensive variation among circulating isolates of subgroup A RS virus, including isolates recovered from infants from the same metropolitan area infected during the same epidemic season that were indistinguishable by MAb analysis. In addition, our findings suggest the possible existence of well-defined genome variants within subgroup A that could be of clinical, epidemiologic, or pathophysiologic importance. Finally, our results are of practical significance in that they demonstrate that ribonuclease protection analysis can serve as a technique for RNA fingerprinting of RS virus that can be applied to studies of the molecular epidemiology and pathogenesis of this and similar viruses.

\section{Acknowledgments}

We are grateful to Charles Reed and Dr. Ella Swierkosz for supplying the RS virus isolates from the Virology Laboratories at St. Louis Children's Hospital and Cardinal Glennon Hospital; to Ann Dunn, R.N. and Dr. Monica Ultmann for providing information about the outbreak at the extended care facility; and to Drs. Larry Gelb, Dan Granoff, Gerald Medoff, and Milton Schlesinger for reviewing the manuscript.

\section{References}

1. Hall, C. B. 1987. Respiratory syncytial virus. In Textbook of Pediatric Infectious Diseases, 2nd ed. R. D. Feigin and J. D. Cherry, editors. W. B. Saunders Co., Philadelphia, PA. 1653-1676. 
2. Glezen, W. P., and F. W. Denny. 1973. Epidemiology of acute lower respiratory disease in children. N. Engl. J. Med. 288:498-505.

3. Coates, H. V., D. W. Alling, and R. M. Chanock. 1966. An antigenic analysis of respiratory syncytial virus isolates by a plaque reduction neutralization test. Am. J. Epidemiol. 83:299-313.

4. Doggett, J. E., and D. Taylor Robinson. 1965. Serologic studies with respiratory syncytial virus. Arch. fur die gesamte virusforschung. 15:601-608.

5. Hierholzer, J. C., and M. S. Hirsch. 1979. Croup and pneumonia in human infants associated with a new strain of respiratory syncytial virus. J. Infect. Dis. 140:826-829.

6. Suto, T., N. Yano, M. Ikeda, M. Miyamoto, S. Takai, S. Shigeta, Y. Hinuma, and N. Ishida. 1965. Respiratory syncytial virus and its serologic epidemiology. Am. J. Epidemiol. 82:211-224.

7. Wulff, H., P. Kidd, and H. A. Wenner. 1964. Respiratory syncytial virus: observations on antigenic heterogeneity. Proc. Soc. Exp. Biol. Med. 115:240-243.

8. Chanock, R. M., and L. Finberg. 1957. Recovery from infants with respiratory illness of a virus related to chimpanzee coryza agent (CCA). II. Epidemiologic aspects of infection in infants and young children. Am. J. Hyg. 66:291-300.

9. Chanock, R. M., H. W. Kim, A. J. Vargosko, A. Deleva, K. M. Johnson, C. Cumming, and R. H. Parrott. 1961. Respiratory syncytial virus. I. Virus recovery and other observations during 1960 outbreak of bronchiolitis, pneumonia, and minor respiratory diseases in children. JAMA (J. Am. Med. Assoc.). 176:647-653.

10. Kim, H. W., J. O. Arrobio, C. D. Brandt, B. C. Jeffries, G. Pyles, J. L. Reid, R. M. Chanock, and R. H. Parrott. 1973. Epidemiology of respiratory syncytial virus infection in Washington, D.C. I. Importance of the virus in different respiratory tract disease syndromes and temporal distribution of infection. Am. J. Epidemiol. 95:216-225.

11. Foy, H. M., M. K. Cooney, R. McMahan, and J. T. Grayston. 1973. Viral and mycoplasmal pneumonia in a prepaid medical care group during an eight-year period. Am. J. Epidemiol. 97:93-102.

12. Henderson, F. W., A. M. Collier, W. A. Clyde, Jr., and F. W. Denny. 1979. Respiratory-syncytial-virus, infections, reinfections and immunity. A prospective, longitudinal study in young children. $N$. Engl. J. Med. 300:530-534.

13. Anderson, L. J., J. C. Hierholzer, C. Tsou, R. M. Hendry, B. F. Fernie, Y. Stone, and K. McIntosh. 1985. Antigenic characterization of respiratory syncytial virus strains with monoclonal antibodies. $J$. Infect. Dis. 151:626-633.

14. Mufson, M. A., C. Orvell, B. Rafnar, and E. Norrby. 1985. Two distinct subtypes of human respiratory syncytial virus. J. Gen. Virol. 66:2111-2124.

15. Hendry, R. M., A. L. Talis, E. Godfrey, L. J. Anderson, B. F. Fernie, and K. McIntosh. 1986. Concurrent circulation of antigenically distinct strains of respiratory syncytial virus during community outbreaks. J. Infect. Dis. 153:291-297.

16. Gimenez, H. B., N. Hardman, H. M. Keir, and P. Cash. 1986. Antigenic variation between human respiratory syncytial virus isolates. J. Gen. Virol. 67:863-870.

17. Storch, G. A., and C. S. Park. 1987. Monoclonal antibodies demonstrate heterogeneity in the $\mathrm{G}$ glycoprotein of prototype strains and clinical isolates of respiratory syncytial virus. J. Med. Virol. 22:345-356.

18. Akerlind, B., and E. Norrby. 1986. Occurrence of respiratory syncytial virus subtypes A and B strains in Sweden. J. Med. Virol. 19:241-247.

19. Tsutsumi, H., M. Onuma, K. Suga, T. Honjo, Y. Chiba, S. Chiba, and P. L. Ogra. 1988. Occurrence of respiratory syncytial virus subgroup A and subgroup B strains in Japan, 1980 to 1987. J. Clin. Microbiol. 26:1171-1174.

20. Morgan, L. A., E. G. Routledge, M. M. Willcocks, A. C. Samson, R. Scott, and G. L. Toms. 1987. Strain variation of respiratory syncytial virus. J. Gen. Virol. 68:2781-2788.

21. Mufson, M. A., R. B. Belshe, C. Orvell, and E. Norrby. 1988.
Respiratory syncytial virus epidemics variable dominance of subgroups A and B strains among children, 1981-1986. J. Infect. Dis. 157:143-148.

22. Johnson, P. R., Jr., R. A. Olmstead, G. A. Prince, B. R. Murphy, D. W. Alling, E. E. Walsh, and P. L. Collins. 1987. Antigenic relatedness between glycoproteins of human respiratory syncytial virus subgroups $A$ and $B$ : evaluation of the contributions of $F$ and $G$ glycoproteins to immunity. J. Virol. 61:3163-3166.

23. Hendry, R. M., J. C. Burns, E. E. Walsh, B. S. Graham, P. F. Wright, V. G. Hemming, W. J. Rodriguez, H. W. Kim, G. A. Prince, K. McIntosh, R. M. Chanock, and B. R. Murphy. 1988. Strain-specific serum antibody responses in infants undergoing primary infection with respiratory syncytial virus. J. Infect. Dis. 157:640-647.

24. Mufson, M. A., R. B. Belshe, C. Orvell, and E. Norrby. 1987. Subgroup characteristics of respiratory syncytial virus strains recovered from children with two consecutive infections. J. Clin. Microbiol. 25:1535-1539.

25. Finger, R., L. J. Anderson, R. C. Dicker, B. Harrison, R. Doan, A. Downing, and L. Corey. 1987. Epidemic infections caused by respiratory syncytial virus in institutionalized young adults. J. Infect. Dis. 155:1335-1339.

26. Walsh, E. E., M. W. Brandriss, and J. J. Schlesinger. 1987. Immunological differences between the envelope glycoproteins of two strains of human respiratory syncytial virus. J. Gen. Virol. 68:21692176.

27. Cash, P., W. H. Wunner, and C. R. Pringle. 1977. A comparison of the polypeptides of human and bovine respiratory syncytial viruses and murine pneumonia virus. Virology. 82:369-379.

28. Gimenez, H. B., P. Cash, and W. T. Melvin. 1984. Monoclonal antibodies to human respiratory syncytial virus and their use in comparison of different viral isolates. J. Gen. Virol. 65:963-971.

29. Ward, K. A., J. S. Everson, P. R. Lambden, and P. J. Watt. 1984. Antigenic and structural variation in the major nucleocapsid protein of respiratory syncytial virus. J. Gen. Virol. 65:1749-1757.

30. Stott, E. J., M. H. Bew, G. Taylor, J. Jabbett, and A. P. Collins. 1984. The characterization and uses of monoclonal antibodies to respiratory syncytial virus. Dev. Biol. Stand. 57:237-244.

31. Norrby, E., M. A. Mufson, and H. Sheshberadaran. 1986. Structural differences between subtype A and B strains of respiratory syncytial virus. J. Gen. Virol. 67:2721-2729.

32. Routledge, E. G., M. M. Willcocks, L. Morgan, A. C. R. Samson, R. Scott, and G. L. Toms. 1987. Heterogeneity of the respiratory syncytial virus $22 \mathrm{~K}$ protein revealed by Western blotting with monoclonal antibodies. J. Gen. Virol. 68:1209-1215.

33. Akerlind, B., E. Norrby, C. Orvell, and M. A. Mufson. 1988. Respiratory syncytial virus: Heterogeneity of subgroup B strains. $J$. Gen. Virol. 69:2145-2154.

34. Johnson, P. R., M. K. Spriggs, R. A. Olmstead, and P. L. Collins. 1987. The $G$ glycoprotein of human respiratory syncytial viruses of subgroups A and B: extensive sequence divergence between antigenically related proteins. Proc. Natl. Acad. Sci. USA. 84:56255629.

35. Myers, R. M., Z. Larin, and T. Maniatis. 1985. Detection of single base substitutions by ribonuclease cleavage at mismatches in RNA:DNA duplexes. Science (Wash. DC). 230:1242-1246.

36. Winter, E., F. Yamamoto, C. Almoguera, and M. Perucho. 1985. A method to detect and characterize point mutations in transcribed genes: amplification and overexpression of the mutant c-Ki-ras allele in human tumor cells. Proc. Natl. Acad. Sci. USA. 82:75757579.

37. Gibbs, R. A., and C. T. Caskey. 1987. Identification and localization of mutations at the Lesch-Nyhan locus by ribonuclease $A$ cleavage. Science (Wash. DC). 236:303-305.

38. Forrester, K., C. Almoguera, K. Han, W. E. Grizzle, and M. Perucho. 1987. Detection of high incidence of K-ras oncogenes during human colon tumorigenesis. Nature (Lond.). 327:298-303.

39. Veres, G., R. A. Gibbs, S. E. Scherer, and C. T. Caskey. 1987 
The molecular basis of the sparse fur mouse mutation. Science (Wash. DC). 237:415-417.

40. Lopez-Galindez, C., J. A. Lopez, J. A. Melero, L. de la Fuente, C. Martinez, J. Ortin, and M. Perucho. 1988. Analysis of genetic variability and mapping of point mutations in influenza virus by the RNase A mismatch cleavage method. Proc. Natl. Acad. Sci. USA. 85:3522-3526.

41. Chanock, R. M., B. Roizman, and R. Myers. 1957. Recovery from infants with respiratory illness of a virus related to chimpanzee coryza agent (CCA). I: Isolation, properties, and characteristics. Am. J. Hyg. 66:281-290.

42. Lewis, F. A., M. L. Rae, N. I. Lehmann, and A. A. Ferris. 1961. A syncytial virus associated with epidemic disease of the lower respiratory tract in infants and young children. Med. J. Aust. 2:932-933.

43. Chirgwin, J. M., A. E. Przybyla, R. J. MacDonald, and W. J. Rutter. 1979. Isolation of biologically active ribonucleic acid from sources enriched in ribonuclease. Biochemistry. 18:5294-5299.

44. Maniatis, T., E. F. Fritsch, and J. Sambrook. 1982. Molecular Cloning: A Laboratory Manual. Cold Spring Harbor Laboratory, Cold Spring Harbor, NY. 196.

45. Wertz, G. W., P. L. Collins, Y. Huang, C. Gruber, S. Levine, and $L$. A. Ball. 1985. Nucleotide sequence of the $G$ protein gene of human respiratory syncytial virus reveals an unusual type of viral membrane protein. Proc. Natl. Acad. Sci. USA. 82:4075-4079.

46. Ding, M., D. Wen, M. J. Schlesinger, G. W. Wertz, and A. L. Ball. 1987. Expression and glycosylation of the respiratory syncytial virus G protein in Saccharomyces cerevisiae. Virology. 159:450-453.

47. Maniatis, T., E. R. Fritsch, and J. Sambrook. 1982. Molecular Cloning: A Laboratory Manual. Cold Spring Harbor Laboratory, Cold Spring Harbor, NY. 252-253.

48. Nottay, B. K., O. M. Kew, M. H. Hatch, J. T. Heyward, and J. F. Obijeski. 1981. Molecular variation of type 1 vaccine-related wild polioviruses during replication in humans. Virology. 108:405-423.

49. Kew, O. M., B. K. Nottay, and J. F. Obijeski. 1984. Applications of oligonucleotide fingerprinting to the identification of viruses. Methods Virol. 7:41-84.

50. Trent, D. W., J. A. Grant, L. Rosen, and T. P. Monath. 1983. Genetic variation among dengue 2 viruses of different geographic origin. Virology. 128:271-284.

51. Holland, J., K. Spindler, F. Horodyski, E. Grabau, S. Nichol, and S. VandePol. 1982. Rapid evolution of RNA genomes. Science (Wash. DC). 215:1577-1585. 